UDC : 394.1.

\author{
Shapsugova M.D. \\ Candidate of Legal Sciences, Associate Professor, Senior Researcher of the Sector of Business \\ and Corporate Law of the Institute of State and Law of the Russian Academy of Sciences
}

\title{
COMMENTARY ON THE SOCIAL ENTREPRENEURSHIP LAW
}

\begin{abstract}
Social entrepreneurship is one of the forms of implementing the principles of social justice and social state. Support for social entrepreneurship development requires developing a legal model and an appropriate legal regime adequate to the economic relations arising in this area. The article analyzes specific provisions of the Federal Law of July 26, 2019, N 245-FZ "On Amendments to the Federal Law" On the Development of Small and Medium-Sized Businesses in the Russian Federation "in terms of consolidating the concepts of" social entrepreneurship "," social enterprise"... In particular, the author concludes that the adopted law's scope does not cover non-profit organizations' activities, which are a typical example of social entrepreneurship. In connection with the emergence of a category of self-employed citizens, as long as their activities are recognized as entrepreneurial, the author considers it appropriate to consider them a potential basis for social entrepreneurship and small business. At the same time, a legislative gap has formed in this area. They also criticized the approach of classifying social entrepreneurship as small and medium.
\end{abstract}

Keywords: social solidarity, non-commercial organizations, social entrepreneurship, small and medium-sized business.

The market economy's fundamental problems include the negative effects generated by it: social inequality, unemployment, climate change, environmental degradation, and others. Social entrepreneurship is aimed precisely at solving these problems. Against the economic crisis background, social entrepreneurship ensures the economic activity of socially unprotected segments of the population, including the disabled, mothers with many children, ensuring their employment, thereby preventing unemployment.

Feature Social Entrepreneurship consists of approaches to control the public processes, allowing stable social organizations and the development of social services[1]. solidarity.

Social entrepreneurship is a practical aspect of the implementation of the principle of

The principle of solidarity is based on the idea of social duty.

No legislative order would be sufficient to ensure the exact payment of social debt; in all aspects of life, each of us's consent is necessary. To be ready to agree to all acts of paying social obligations means genuinely being a human society member and a social being [2].

Kadol N.F. identifies three categories of actions in social entrepreneurship: results;

1) "integrated social entrepreneurship" - the purpose of which is to create social profit and

2) "reinterpretation" - the use of existing opportunities for non-profit organizations to increase income, reduce their costs to the organization, and diversify sources of income; 
3) "interacting social entrepreneurship", manifests itself in the non-profitability of the entrepreneurial activity of the organization[3].

The aim of forming and developing social entrepreneurship as a complex legal institution is the resolution of social conflicts, support for socially significant problems, and, ultimately, the implementation of social justice and the welfare state.

The implementation of this goal requires:

- analysis of theoretical approaches to understanding social entrepreneurship

- a systematic interdisciplinary approach to the understanding of social entrepreneurship

- research of the institution of social entrepreneurship to implement the principle of social justice and the transition from the classical model of a market economy to its socially-oriented model.

- development of an optimal legal model of social entrepreneurship based on the analysis of economic relations emerging in this area and economic approaches to understanding social entrepreneurship

- analysis of the possibilities of implementing the legislative model of social entrepreneurship with the help of the institutions of family entrepreneurship, self-employment, and entrepreneurial activities of non-profit organizations.

- scientific substantiation of the goals and objectives of the legal regulation of social entrepreneurship, the study of the current legislation, the means and methods used by the legislator to achieve the goals and objectives of the legal regulation of the investigated sphere of legal regulation.

- development of proposals for improving legislation on social entrepreneurship based on the developed legal model of social entrepreneurship.

The idea of realizing the principle of social justice through social entrepreneurship means, in fundamental terms, a transition from the model of a classical market economy to a model of a socially-oriented market economy.

The development of social entrepreneurship in Russia is impeded by the imperfection of social entrepreneurship's legal regulation, the lack of an integrated systematic approach to the formation of the conditions for its activity, and the underdevelopment of alternative financing mechanisms social entrepreneurship and their legal support.

The study's relevance is also due to the latest changes in Russian legislation that need scientific understanding. The need for legislative regulation of social entrepreneurship, especially in terms of social entrepreneurs' benefits, has been discussed for many years. Their result was the adoption of the Federal Law of July 26, 2019, N 245-FZ "On Amendments to the Federal Law" On the Development of Small and Medium-Sized Businesses in the Russian Federation "in terms of consolidating the concepts of" social entrepreneurship, "" social enterprise" [4].

It is possible to highlight some features of social entrepreneurship's legislative model, enshrined in this law.

The law introduces a social enterprise concept, a small or medium-sized business entity operating in social entrepreneurship.

In the law, social entrepreneurship is understood as an entrepreneurial activity aimed at achieving socially useful goals, contributing to the solution of social problems of citizens and society, and carried out by the conditions provided for by this law. He also secured the approach depending on the dollars and income of social enterprise on the types of activities with a social orientation and labor costs listed in socially unprotected citizens. 
Simultaneously, the list of activities subject to the legal regime of social entrepreneurship is exhaustive. It can also be noted that not all types of activities attributed to social entrepreneurship are included in the law.

The social entrepreneurship model, enshrined in legislation, requires critical scientific analysis, forecasting trends in its implementation in practice to identify its conceptual imperfection and develop proposals for optimization.

The analysis should be based on an integrated cross-sectoral approach. We put forward a hypothesis that the legal model of social entrepreneurship developed by the legislator does not fully correspond to the socio-economic nature of social entrepreneurship. Therefore, its legal regulation's goals and objectives and the means and methods used become unattainable.

Based on the analysis of legislative changes, we come to the sad conclusion that the social and entrepreneurial activities of non-profit organizations fell outside the scope of the abovementioned adopted law since they are not classified as small and medium-sized businesses by the law, in which the norms on social entrepreneurship are incorporated. At the same time, some scholars understand social entrepreneurship as an independent direction of entrepreneurial activity, different from a non-profit organization [5]. Non-profit organizations engaged in entrepreneurial activities to achieve socially worthwhile goals cannot be classified as SMEs, because according to Part 1 of Art. 4 of the Federal Law of July 24, 2007 No. 209-FZ "On the Development of Small and Medium-Sized Businesses in the Russian Federation", SMEs are those registered under the legislation of the Russian Federation and corresponding to the conditions established by Part . 1.1 Art. 4 of the Federal Law "On the Development of Small and Medium-Sized Businesses", business societies, business partnerships, business partnerships, production cooperatives, consumer cooperatives, peasant (farming) enterprises, and individual entrepreneurs. Therefore, this law does not apply to non-profit organizations.

Simultaneously, the legal personality of non-profit organizations is aimed precisely at achieving a socially beneficial effect and solving socially significant problems. Besides, it allows for entrepreneurial activities.

Thus, in an economic sense, a non-profit organization's entrepreneurial activity is a classic example of social entrepreneurship. The reasons why their activities do not fall within the scope of the adopted law are not clear.

Social entrepreneurship's attribution to small and medium-sized entrepreneurship from its economic nature is critically perceived. The current legislation provides for the legal regulation of social entrepreneurship within the framework of small and medium-sized businesses. This approach seems to be conceptually incorrect. It seems that it is unreasonably narrowed, also because it does not take into account the social entrepreneurship of non-profit organizations whose activities do not fall within the scope of this law. This approach cannot be recognized as correct, also because a large enterprise can also be socially oriented. Perhaps the purpose of adopting this law was to support precisely small and medium-sized businesses, but this does not fully reflect social entrepreneurship's economical nature.

Another category of entrepreneurs, not taken into account either by the Federal Law "On the Development of Small and Medium-Sized Businesses," or by the amendments made to it on social entrepreneurship, are self-employed. However, self-employment carries the considerable potential for the development of social entrepreneurship, in our opinion.

From the adopted law, social entrepreneurship's central meaning as a form of implementation of the constitutional and legal principle of social justice and a social state is not obvious. Those state social tasks and national interests approach resolving social contradictions 
and conflicts for which it was actually adopted. We believe that further work is needed on a model of legal regulation of social entrepreneurship, taking into account the interests of the state, business, and citizens, taking into account all categories of social entrepreneurship entities, including non-profit organizations.

We believe that the adopted law does not fully meet the economic criteria of social entrepreneurship either in terms of the range of subjects that carry it out or the types of activities it refers to as social entrepreneurship.

The concept of social entrepreneurship is narrowly stated in the new law.

\section{References}

1. Kadol N.F. Social entrepreneurship in market and transitional economies. Candidate of Science in Economics. - M., 2009. P. 8.

2. Novgorodtsev P. The crisis of modern legal consciousness. - M., 1909. P. 379.

3. Kadol N.F. Social entrepreneurship in market and transitional economies. Candidate of Science in Economics. - M., 2009. P. 8.

4. Consultant Plus [Electronic resource] https://clck.ru/QsrKs (accessed 05.09. 2020)

5. Battakhov P.P.SOCIAL ENTREPRENEURSHIP IN RUSSIA: SOME ISSUES OF LEGAL REGULATION // Issues of Labor Law. 2020. No. 6. Pp. 17-22. 